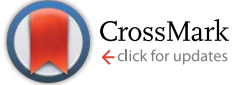

Cite this: RSC Adv., 2015, 5, 51812
Received 30th April 2015

Accepted 1st June 2015

DOI: $10.1039 / \mathrm{c} 5 \mathrm{ra07997g}$

www.rsc.org/advances

\section{Complete dissipation of 2,4,6-trinitrotoluene by in-vessel composting $\dagger$}

\author{
Burcu Gumuscu, ${ }^{\text {*ab }}$ Deniz Cekmeceliogluc ${ }^{c}$ and Turgay Tekinay ${ }^{\text {de }}$
}

We demonstrate complete removal of 2,4,6-trinitrotoluene (TNT) in 15 days using an in-vessel composting system, which is amended with TNT-degrading bacteria strains. A mixture of TNT, food waste, manure, wood chips, soil and TNT-degrading bacteria consortium are co-composted for 15 days in an aerobic environment. Variations in the TNT degradation rates are assessed when composting reactors are operated at different carbon/nitrogen ratios $(\mathrm{C} / \mathrm{N})$, aeration rates, TNT concentrations and TNT-degrading bacteria inoculum loads. Changes in TNT concentrations are measured using high performance liquid chromatography, and $\mathrm{C} / \mathrm{N}$ are determined using elemental analysis every 5 days. Temperature and moisture of the system are measured every 6 hours. Optimum TNT degradation performance is achieved by combining $\mathrm{C} / \mathrm{N}$ of $20 / 1$ and a $5 \mathrm{~L} \mathrm{~min}^{-1}$ aeration rate. Complete removal is achieved for TNT concentrations of 2,10 , and $100 \mathrm{~g} \mathrm{~kg}^{-1}$ in 15 days by the help of Citrobacter murliniae STE10, Achromobacter spanius STE11, Kluyvera cryocrescens STE12, and Enterobacter amnigenus STE13 bacteria strains. The final products of composting are used to cultivate four different plant seedlings for 10 weeks and showed no toxic effect, which is promising for the potential agricultural use of TNT-contaminated lands after remediation.

\section{Introduction}

2,4,6-Trinitrotoluene (TNT) has been utilized widely in military and industrial applications for almost 150 years. Manufacture, storage, and handling of TNT have resulted in substantial contamination of soil and groundwater. Since TNT is known to be toxic, ${ }^{1}$ mutagenic, and carcinogenic ${ }^{2}$ to living organisms, remediation of this contaminant is highly desired. ${ }^{3}$

Composting serves as an effective bioremediation method thanks to low implementation costs and environmentally friendly end-products. The operating costs per cubic yard are in a range of 80 to $20000 \$$ for widely-used remediation techniques, including phytoremediation, ${ }^{4}$ excavation, ${ }^{5}$ soil washing, ${ }^{6}$ incineration, ${ }^{7}$ and soil vapor extraction, ${ }^{8}$ while the composting method costs only $25 \$ .^{9}$ TNT can be transformed to organic substrates by controlled degradation and mineralization in

${ }^{a}$ Bilkent University, UNAM - Institute of Materials Science and Nanotechnology, 06800, Ankara, Turkey

${ }^{b}$ University of Twente, MESA+ Institute for Nanotechnology, 7500 AE, Enschede, The Netherlands.E-mail: b.gumuscu@utwente.nl

${ }^{c}$ Middle East Technical University, Department of Food Engineering, 06800, Ankara, Turkey

${ }^{d}$ Gazi University, Life Sciences Application and Research Center, 06830, Ankara, Turkey

${ }^{e}$ Gazi University, Department of Medical Biology and Genetics, Faculty of Medicine, 06500 Ankara, Turkey

$\dagger$ Electronic supplementary information (ESI) available. See DOI: 10.1039/c5ra07997g composting systems, which are promising to remediate munitions-contaminated lands for agricultural use..$^{\mathbf{1 0 , 1 1}}$

Various composting methods have been documented for treatment of TNT-amended soils. A windrow composting study showed TNT biodegradation ability of various microorganisms on site in $1978,{ }^{12}$ that was followed by a simulated composting work where native microbial colonies from surface soil and groundwater were reported to degrade TNT. ${ }^{\mathbf{1 0}}$ Breitung et al. demonstrated that $92 \%$ of initial TNT amount can be removed by two different aerated composting systems. ${ }^{13}$ In another study, Bruns-Nagel et al. reported the removal of TNT and its transformation products in composting reactors within 65 days. ${ }^{\mathbf{1 4}}$

Among composting approaches, in-vessel composting is particularly advantageous for treatment of munitionscontaminated soils because it features a well-controlled compact system with uniform mixture structure and high process efficiency. ${ }^{15}$ In-vessel composting is of preference to maximize the removal of nitroaromatic compounds and to enable the usage of the final composts for industrial and agricultural purposes. Antizar-Ladislao et al. ${ }^{\mathbf{1 6}}$ reported polycyclic aromatic hydrocarbon degradation within 98 days in an invessel composting system, in which the microbial population was traced during composting maturation period. Canet et al. ${ }^{17}$ demonstrated the conversion of the nitroaromatic compounds into organic substrates via native microorganisms in an invessel composting system.

Previous studies have shown that in-vessel composting is an effective method for treatment of contaminated soils; however, two major questions yet to be answered are how initial TNT 
concentration impacts compost maturation and contaminant removal rate during composting; and how the addition of TNT-degrading bacteria effects the duration and efficiency of composting. Thus, the present study was conducted to assess the relation between the initial TNT concentration and removal rates, and to enable rapid and complete degradation of TNT using specific bacteria in an in-vessel composting system by optimizing the variable conditions. Four TNT-degrading bacteria isolates that increased TNT degradation rate were Citrobacter murliniae STE10, Achromobacter spanius STE11, Kluyvera cryocrescens STE12, and Enterobacter amnigenus STE13.

\section{Experimental}

\section{Chemicals and reagents}

Standards of TNT; 2,4-aminodinitrotoluene (2,4-DNT); 2,6-aminodinitrotoluene (2,6-DNT); 4-aminonitrotoluene (4-ADNT); 2-aminonitrotoluene (2-ADNT) $\left(1000 \mu \mathrm{g} \mathrm{mL} \mathrm{m}^{-1}\right.$ in acetonitrile, purity $<99.9 \%$ ) were purchased from SupelCo (USA). HPLC-grade acetonitrile (Sigma-Aldrich) was utilized for the extraction of TNT from composting samples, and double distilled water (Millipore, USA) and methanol (Sigma-Aldrich) were used in the HPLC measurements. Chromafil PET-20/25 membrane filters $(0.2 \mu \mathrm{m}$, Macherey-Nagel, USA) were used for filtration of samples.

\section{Compost amendments}

Food waste was collected from dining halls and cafeterias at the Middle East Technical University campus, Ankara. In general, the food waste consisted of bread, red pepper, lemon, cracked wheat, rice, carrot, napkin, beans, peas, tomato, parsley, lettuce, and yoghurt. Cow manure was obtained from local farms in Ankara and wood chips (0.8-2.7 cm long) were obtained from Farm Operations at Middle East Technical University. Greenhouse soil was obtained from greenhouse of Bilkent University to be used in composting experiments and toxicity tests. TNT-degrading bacteria strains were isolated from TNT-contaminated samples that were collected from TNT manufacturing and explosion site. TNT was obtained from Mechanical and Chemical Industry Corporation-Kırıkkale Brass Factory, Turkey.

Carbon/nitrogen determination. Compost amendments were separately dried for $24 \mathrm{~h}$, and then pulverized via a mortar. Carbon and nitrogen compositions of compost amendments were determined via a Flash $2000 \mathrm{CHNS} / \mathrm{O}$ Element Analyzer (Thermo Scientific, USA). Table 1 demonstrates the typical

Table 1 Mean and standard error deviation of carbon, nitrogen and moisture values of compost amendments, $n=12$

\begin{tabular}{llccl}
\hline Material & \multicolumn{1}{l}{$\begin{array}{l}\text { Food } \\
\text { waste }\end{array}$} & Manure & \multicolumn{1}{l}{$\begin{array}{l}\text { Wood } \\
\text { chips }\end{array}$} & $\begin{array}{l}\text { Green-house } \\
\text { soil }\end{array}$ \\
\hline $\begin{array}{l}\text { Carbon } \\
(\%)\end{array}$ & $43.39 \pm 4.90$ & $11.58 \pm 0.80$ & $55.40 \pm 3.40$ & $14.54 \pm 1.90$ \\
$\begin{array}{l}\text { Nitrogen } \\
(\%)\end{array}$ & $1.27 \pm 0.30$ & $1.25 \pm 0.20$ & $0.30 \pm 0.05$ & $1.01 \pm 0.20$ \\
$\begin{array}{l}\text { C/N } \\
\begin{array}{l}\text { Moisture } \\
(\%)\end{array}\end{array}$ & $74.59 \pm 7.16 \pm 2.70$ & $9.26 \pm 1.20$ & $184.66 \pm 12.45$ & $14.40 \pm 0.70$ \\
& & $37.70 \pm 1.10$ & $11.18 \pm 1.20$ & $45.86 \pm 3.30$ \\
& & & &
\end{tabular}

carbon, nitrogen, and moisture contents of the materials that were used in experiments.

After determining the carbon and nitrogen contents of the composting amendments, $\mathrm{C} / \mathrm{N}$ of composting mixtures were determined using the eqn (1); where $a$ is the total weight of ingredient $\mathrm{a} ; b$ is the total weight of ingredient $\mathrm{b} ; m_{\mathrm{a}}, m_{\mathrm{b}}$, etc. represent the moisture content of ingredients $\mathrm{a}, \mathrm{b}$, etc.; $\% \mathrm{C}_{\mathrm{a}}, \mathrm{C}_{\mathrm{b}}$, etc. are the $\%$ carbon of ingredients $\mathrm{a}, \mathrm{b}$, etc.; and $\% \mathrm{~N}_{\mathrm{a}}, \mathrm{N}_{\mathrm{b}}$, etc. are the $\%$ nitrogen of ingredients $\mathrm{a}, \mathrm{b}$, etc. ${ }^{15}$

$$
\frac{\mathrm{C}}{\mathrm{N}} \text { ratio }=\frac{\left[\% \mathrm{C}_{\mathrm{a}} a\left(1-m_{\mathrm{a}}\right)\right]+\left[\% \mathrm{C}_{\mathrm{b}} b\left(1-m_{\mathrm{b}}\right)\right]+\ldots}{\left[\% \mathrm{~N}_{\mathrm{a}} a\left(1-m_{\mathrm{a}}\right)\right]+\left[\% \mathrm{~N}_{\mathrm{b}} b\left(1-m_{\mathrm{b}}\right)\right]+\ldots}
$$

TNT-degrading bacteria. For isolation of TNT-degrading bacteria, contaminated samples were obtained from a TNT manufacturing and explosion site in Elmadag, Turkey. Visibly discoloured soil sections and bottom sediments of pink water regions were collected to a depth of $5-10 \mathrm{~cm}$ using spatulas and sterile polypropylene tubes. TNT concentrations of the samples were in a range of $20-245 \mathrm{mg} \mathrm{kg}^{-1}$.

Immediately after collection, the samples were inoculated with $0.1 \%(\mathrm{v} / \mathrm{w})$ suspension in M8 media, ${ }^{18}$ which contained 60 $\mathrm{g} \mathrm{L}^{-1} \mathrm{Na}_{2} \mathrm{HPO}_{4}, 30 \mathrm{~g} \mathrm{~L}^{-1} \mathrm{KH}_{2} \mathrm{PO} 4,5 \mathrm{~g} \mathrm{~L}^{-1} \mathrm{NaCl}, 10 \mathrm{~mL}$ of $5 \%$ glucose, and $100 \mathrm{mg} \mathrm{L}^{-1} \mathrm{TNT}$. Enrichments were transferred to M8 agar plates $(0.1 \%, v / v)$ and incubated overnight for isolation of bacteria colonies. Among the isolated single colonies, four strains showed the highest TNT degradation capacity in our previous study, in which TNT degradation occurred at $30{ }^{\circ} \mathrm{C}$ in the dark within $20 \mathrm{~h} .{ }^{19}$ Accordingly, Citrobacter murliniae STE10, Achromobacter spanius STE11, Kluyvera cryocrescens STE12, and Enterobacter amnigenus STE13 strains were identified by $16 \mathrm{~S}$ intergenic spacer ribosomal DNA analysis. For DNA isolation, DNeasy Blood \& Tissue Kit (QIAGEN, Germany) was used. The procedure described in Rijpens et al. ${ }^{20}$ was followed for PCR amplification and sequencing steps. The sequence results were submitted to the National Center for Biotechnology Information (NCBI) BLAST database (http:// blast.ncbi.nlm.nih.gov/Blast.cgi) under the access number KF537334 for Citrobacter murliniae STE10, JX312286 for Acinetobacter spanius STE11, KF537333 for Kluyvera cryocrescens STE12, and KF537332 for Enterobacter amnigenus STE13. All of the strains were Gram negative, rod shaped, non-sporeforming, and aerobic bacteria.

Temperature and $\mathrm{pH}$ values were assessed to obtain the maximum TNT removal by TNT-degrading bacteria. Using the protocol in our previous work, ${ }^{19}$ decomposed TNT $\left(\mu \mathrm{g} \mathrm{L}{ }^{-1}\right)$ per day, or TNT degradation rate, ${ }^{17}$ was measured in a temperature range of $0-55{ }^{\circ} \mathrm{C}$ and in $\mathrm{pH}$ range of 1-14.

\section{Experimental design}

In preliminary experiments, greenhouse soil without addition of TNT was utilized to determine optimal $\mathrm{C} / \mathrm{N}$ and aeration rate. Remainder experiments were performed using TNT-amended greenhouse soil. Minitab software was used to determine eleven experimental conditions based on $\mathrm{C} / \mathrm{N}$, aeration rate, TNT concentration, and concentration of bacteria consortium. 
Carbon/nitrogen ratio. Carbon/nitrogen ratio is an important indicator of organic content decomposition in composting mixture. When organic content decays, $\mathrm{C} / \mathrm{N}$ decreases because carbon will be dissipated faster compared to nitrogen. ${ }^{21}$ Starting the experiment with low $\mathrm{C} / \mathrm{N}$ (smaller than 15) slows down the decomposition and microbial activity, while high $\mathrm{C} / \mathrm{N}$ (greater than 35) is not convenient for microorganisms to start decomposition. ${ }^{21}$ Our experimental design, therefore, comprised two carbon/nitrogen ratios $(\mathrm{C} / \mathrm{N}=20 / 1$ and $\mathrm{C} / \mathrm{N}=30 / 1)$ to investigate suitable conditions for improving TNT removal efficiency of the bacteria strains.

Aeration rate. We aerated the composting reactors in order to supply oxygen to aerobic microorganisms including TNT-degrading bacteria, and to maintain the moisture content by evaporation of water. Aeration also helps to cool down the system, preventing excessive heat generation. In our reactors, aeration rates of 5-7 $\mathrm{L} \mathrm{min}^{-1}$ maintained the desired moisture content as well as supplying enough oxygen to the system for microbial activity. We investigated the influence of $\mathrm{C} / \mathrm{N}$ at various aeration rates $\left(5\right.$ and $\left.7 \mathrm{~L} \mathrm{~min}^{-1}\right)$ to obtain the optimal operational parameters for maximum TNT removal.

TNT concentration. Removal of low $\left(2 \mathrm{~g} \mathrm{~kg}^{-1}\right)$, high (10 $\mathrm{g} \mathrm{kg}^{-1}$ ), and extreme (100 $\left.\mathrm{g} \mathrm{kg}^{-1}\right)$ concentrations of TNT was studied using TNT-degrading bacteria strains to investigate how initial TNT concentration impacts compost maturation and contaminant removal rate during composting. To achieve this, TNT was dissolved in acetonitrile $(1: 4, \mathrm{v} / \mathrm{v})$ and blended with the other compost amendments. After determining the optimal $\mathrm{C} / \mathrm{N}$ and aeration rate in non-amended composts, we used TNT-amended composts to evaluate the contaminant removal rate.

Bacteria consortium. The effect of TNT-degrading bacteria on the duration of composting was also studied in context of TNT removal efficiency. Two different concentrations of TNT-degrading bacteria consortium $(0.1 \%$ and $1 \%$, w/w) were used. ${ }^{22}$ Control reactors were not amended with any bacteria consortium. We determined the influence of TNT-degrading bacteria on TNT removal by combining three different TNT concentrations with the optimal $\mathrm{C} / \mathrm{N}$ and aeration rate.

\section{Reactor design}

In-vessel composting system consisted of three vertical cylinder reactors, each with a volume of $10 \mathrm{~L}$. The reactors were covered with glass fibers to ensure heat insulation. Aeration was supplied by an air-compressor and airflow was provided at the bottom side of reactors by cuprous aeration tubes. Perforated stainless steel plates were placed at the bottom side the reactors to uniformly aerate the composting mixtures. In order to avoid gas accumulation in reactors during experiments, air was discharged from an exit line at the top. Temperature was recorded every $6 \mathrm{~h}$ at the midpoints of the reactor and the composting mixture. A schematic view of the system is depicted in Fig. 1. Composting amendments (TNT-degrading bacteria, soil, manure, food waste, wood chips and TNT) were mixed manually in the pre-specified order outside the reactors and then loaded in the reactors. TNT-degrading bacteria were introduced to the composting mixtures to enhance the TNT degradation rate; manure was used

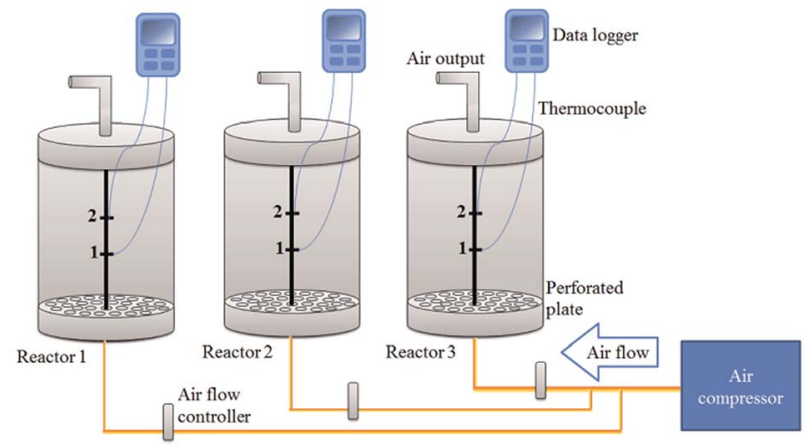

Fig. 1 Schematic view of in-vessel composting reactors. Temperature was recorded using thermocouples that are connected to midpoints 1 and 2 . Yellow lines present cuprous aeration tubes.

to enrich the native bacteria population as well as to increase carbon and moisture contents of the compost mixtures; wood chips were used to form a porous compost mixture for aeration.

\section{In-vessel composting operation}

Two intermittent aerations ( 5 min on per 55 min off cycles) were tested for aeration rates of 5 and $7 \mathrm{~L} \mathrm{~min}^{-1}$. Using these two aeration rates, compost incubation period was determined to be 15 days. The moisture of composts was kept between $50-60 \%$ for all runs.

Sequential runs were performed by the addition of low $(0.1 \%$, $\mathrm{w} / \mathrm{w})$ or high $(1 \%, \mathrm{w} / \mathrm{w})$ concentrations of TNT-degrading bacteria (Citrobacter murliniae STE10, Achromobacter spanius STE11, Kluyvera cryocrescens STE12, and Enterobacter amnigenus STE13) to the reactors in order to stimulate the complete removal of TNT in ex situ. Each strain was added to the consortium in equal proportions. The amount of TNT-degrading bacteria consortium was determined to be either $0.1 \%$ or $1 \%$ (w/w) of entire compost mixture. The calculations were made on dry weight basis. After the addition of TNT-degrading bacteria consortium, TNT was dissolved in acetonitrile $(1: 4, \mathrm{v} / \mathrm{v})$ and blended with the other compost amendments.

\section{Compost analysis}

Sampling and determination of moisture, $\mathrm{pH}$, and $\mathrm{C} / \mathrm{N}$. During the composting period, samples were collected in triplicates from different areas of the composting reactors every 5 days and mixed to form a representative sample, which was then used to determine moisture, $\mathrm{pH}$, carbon, and nitrogen contents. The temperature of the compost was recorded by thermocouples every $6 \mathrm{~h}$.

For moisture measurements and elemental analysis, 1-3 $\mathrm{g}$ of the samples were oven-dried at $105^{\circ} \mathrm{C}$ for $24 \mathrm{~h}$. The dry samples were then pulverized, and analysed via Flash $2000 \mathrm{CHNS} / \mathrm{O}$ Element Analyzer. The method described in ref. 23 was used to determine carbon and nitrogen compositions. In addition, $\mathrm{pH}$ was determined potentiometrically using an electronic $\mathrm{pH}$ probe (Metler Toledo, USA).

Detection of TNT and its metabolites. HPLC studies were carried out for detection of TNT and its degradation products in 
composting samples. Compost samples were blended with $50: 50(\mathrm{v} / \mathrm{v})$ acetonitrile and the blends were placed in an ultrasonic bath for $6 \mathrm{~h}$. After centrifugation at $15000 \mathrm{rpm}$ for $15 \mathrm{~min}$, the supernatant of the blends were purified using $0.2 \mu \mathrm{m}$ membrane filter. Finally, $1.5 \mu \mathrm{L}$ of extract from each sample was collected for HPLC analysis. Extracts were analysed immediately after the preparation.

All measurements were performed on Agilent 1200 Series HPLC system consisting of Agilent 1200 Degasser, 1200 isocratic pump, 1200 ALS auto sampler, and 1200 MWD multi wavelength detector. The operation wavelength of the study was set at $254 \mathrm{~nm}$. Analyses and quantification of the results were performed using HP Chemstation software. The system was calibrated with 5 different sample standards prior to the measurements. A diol column $(4.6 \mathrm{~mm} \times 150 \mathrm{~mm}, 3 \mu \mathrm{m})$ was used in measurements and the injection volume was $5 \mu \mathrm{L}$. Mobile phases were methanol and distilled water. A gradient method was utilized for the quantification of TNT and TNT metabolites. Initial methanol ratio was raised from $10 \%$ to $60 \%$ between $0-18 \mathrm{~min}$. From $18 \mathrm{~min}$ to 25 min, methanol ratio was decreased to $20 \%$ again. ${ }^{24}$

Determination of bacteria cell numbers. Bacteria cell numbers of the compost were determined by the dilution and spread-plate methods using Luria Bertani (LB) enrichment medium. In order to achieve this, composting samples were collected in sterile polystyrene tubes on $1^{\text {st }}$ and $15^{\text {th }}$ days of the experiments. Collected samples were immediately inoculated in LB broth and incubated overnight at $30{ }^{\circ} \mathrm{C}$ on a rotary shaker (125 rpm). Consecutive $1: 10$ serial dilutions were prepared, starting with $1 \mathrm{~mL}$ of sample to produce ten dilutions of each sample. Each dilution was spread onto LB agar plates to obtain single colonies and overnight grown colonies were counted.

Toxicity test. The final composts were tested for their toxicity against terrestrial plant species. Four representative species of Plantae familia, including pelargonium (Pelargonium domesticum) tomato (Solanum lycopersicum), wheat (Triticum aestivum), and corn (Zea mays) were obtained from Bilkent University greenhouse and were cultivated in the same greenhouse. Approximately 1 week old seedlings of the representative plant species were grown in greenhouse soil amended with $100 \mathrm{~g} \mathrm{~kg}^{-1}$ of TNT, non-amended greenhouse soil and the final compost. The greenhouse soils had no prior contamination with TNT. The plant growth was observed for 10 weeks and shoot lengths of the seedlings were measured weekly for growth rate evaluation. All toxicity experiments were replicated twice.

\section{Statistical analysis}

The effect of different variables on TNT degradation rates were evaluated by ANOVA and Tukey test using Minitab (Minitab Inc., USA), which is a statistical software package. The level of significance was set at alpha of 0.05 .

\section{Results and discussion}

\section{Composting process}

Three TNT concentrations and two TNT-degrading bacteria consortium concentrations were tested in subsequent composting experiments in order to assess the relation between the initial TNT concentration and degradation rates. Maturation and stability of composts were examined both physically and chemically. The physical characteristics were the same for all compost mixtures, which were granular and dark-coloured at the end of the composting period (15 days). The odour of final compost mixtures was similar to fresh soil and no foul odour was noticed. For chemical examination, temperature was monitored every $6 \mathrm{~h}$ at two different positions within the compost pile. Temperature changes were considered as one of the primary indicators of microbial activity and TNT removal rate. ${ }^{25}$

Carbon/nitrogen ratio and aeration rate. Two different $\mathrm{C} / \mathrm{N}$ (20/1 and 30/1) were used to determine the optimal operational conditions for complete TNT removal because compost maturation did not occur at lower or higher $\mathrm{C} / \mathrm{N}$ in preliminary experiments. Similarly, two different aeration rates $(5$ and $7 \mathrm{~L}$ $\min ^{-1}$ ) were used for determination of the optimal operational conditions. Compost moisture could not be maintained at higher aeration rates, while lower rates were not sufficient to aerate the reactor. The average temperature profile is shown in Fig. 2, where the mesophilic, thermophilic, cooling and curing stages were observed. Temperature climbed to the upper mesophilic $\left(\sim 39{ }^{\circ} \mathrm{C}\right)$ and lower thermophilic $\left(\sim 49{ }^{\circ} \mathrm{C}\right)$ ranges during the first 6 days of composting and then dropped to ambient conditions. Upper mesophilic and lower thermophilic ranges were dependent on $\mathrm{C} / \mathrm{N}$ and aeration as shown in Fig. 2. The highest temperature was recorded on day 6 as $44^{\circ} \mathrm{C}$ for $\mathrm{C} / \mathrm{N}$ $=30 / 1$ (aerated at $5 \mathrm{~L} \mathrm{~min}^{-1}$ ) and $49.1{ }^{\circ} \mathrm{C}$ for $\mathrm{C} / \mathrm{N}=20 / 1$ (aerated at $5 \mathrm{~L} \mathrm{~min}^{-1}$ ) in Fig. 2a. Temperature trends in Fig. 2 indicate that all reactors contained active aerobic microbial content.

Composts with $\mathrm{C} / \mathrm{N}=30$ were observed to have lower temperature profile compared to $\mathrm{C} / \mathrm{N}=20$ mixtures. A plateau pattern was observed when the reactors were operated at $\mathrm{C} / \mathrm{N}=20$ and $\mathrm{C} / \mathrm{N}=30$ with a constant aeration rate of $5 \mathrm{~L}$ $\min ^{-1}$ (Fig. 2a). The curve's plateau indicates that microbial activity was continuous in between days $5-10$. In Fig. 2 b, the peak temperature values were $35.2{ }^{\circ} \mathrm{C}$ at $7 \mathrm{~L} \mathrm{~min}^{-1}(\mathrm{C} / \mathrm{N}=20 / 1)$, and $49.1{ }^{\circ} \mathrm{C}$ at $5 \mathrm{~L} \mathrm{~min}^{-1}(\mathrm{C} / \mathrm{N}=20 / 1)$, showing a significant difference in temperature profile $(P<0.05)$. After 6 days, temperature of composting mixtures started to gradually decrease and reached an ambient level on day 15. These results
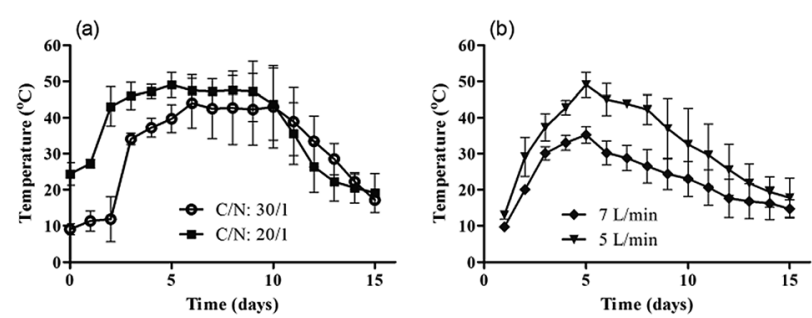

Fig. 2 Temperature change in composts without TNT amendment and bacteria inoculation. (a) Different $\mathrm{C} / \mathrm{N}$ combined with a constant aeration rate of $5 \mathrm{~L} \mathrm{~min}{ }^{-1}$, (b) different aeration rates combined with a constant $\mathrm{C} / \mathrm{N}$ of 20/1. Error bars present the standard deviation, $n=2$. 
Table 2 TNT degradation rate $\left(k^{\prime}\right)$ at various composting conditions per day for (a) $\mathrm{C} / \mathrm{N}=20$, and (b) $\mathrm{C} / \mathrm{N}=30$. The variation of data was presented by standard deviation, $n=2^{b}$

\begin{tabular}{|c|c|c|c|}
\hline \multirow{2}{*}{$\frac{\text { (a) } \mathrm{C} / \mathrm{N}=20}{\text { Aeration rate }}$} & \multicolumn{3}{|c|}{ TNT concentration } \\
\hline & $2 \mathrm{~g} \mathrm{~kg}^{-1}$ & $10 \mathrm{~g} \mathrm{~kg}^{-1}$ & $100 \mathrm{~g} \mathrm{~kg}^{-1}$ \\
\hline $\begin{array}{l}5 \mathrm{~L} \mathrm{~min}^{-1} \\
7 \mathrm{~L} \mathrm{~min}^{-1}\end{array}$ & $\begin{array}{l}0.024 \pm 0.001^{\mathrm{A}, \mathrm{a}} \\
0.022 \pm 0.003^{\mathrm{A}, \mathrm{a}}\end{array}$ & $\begin{array}{l}0.024 \pm 0.001^{\mathrm{A}, \mathrm{a}} \\
0.018 \pm 0.004^{\mathrm{B}, \mathrm{b}}\end{array}$ & $\begin{array}{l}0.022 \pm 0.001^{\mathrm{A}, \mathrm{b}} \\
{ }^{a} \mathrm{NP}\end{array}$ \\
\hline
\end{tabular}

\begin{tabular}{lll}
\hline (b) $\mathrm{C} / \mathrm{N}=30$ & \multicolumn{2}{c}{ TNT concentration } \\
\cline { 2 - 3 } Aeration rate & $2 \mathrm{~g} \mathrm{~kg}^{-1}$ & $10 \mathrm{~g} \mathrm{~kg}^{-1}$ \\
\hline $5 \mathrm{~L} \mathrm{~min}^{-1}$ & $0.024 \pm 0.003^{\mathrm{A}, \mathrm{a}}$ & $0.024 \pm 0.002^{\mathrm{A}, \mathrm{a}}$ \\
$7 \mathrm{~L} \mathrm{~min}^{-1}$ & $0.029 \pm 0.001^{\mathrm{A}, \mathrm{b}}$ & $0.031 \pm 0.003^{\mathrm{B}, \mathrm{b}}$
\end{tabular}

${ }^{a}$ NP: not performed. ${ }^{b}$ Lower and upper case letters present significant difference. $k^{\prime}$ values not followed by the same type of letter are significantly different at $P<0.05$. Upper case letters are for row comparison and lower case letters are for column comparison.

suggest that degradable material in compost mixture was more accessible when the reactors were operated at $5 \mathrm{~L} \mathrm{~min}{ }^{-1}$ aeration rate and $\mathrm{C} / \mathrm{N}=20$.

TNT degradation rate. TNT degradation rate $\left(k^{\prime}\right)$ was determined by the TNT concentration decrease per day. $k^{\prime}$ was evaluated when different aeration and $\mathrm{C} / \mathrm{N}$ ratio parameters were applied. In compost mixtures operated at $7 \mathrm{~L} \mathrm{m^{-1 }}$ aeration rate, $k^{\prime}$ difference between $\mathrm{C} / \mathrm{N}=20$ and $\mathrm{C} / \mathrm{N}=30$ was 0.005 for $2 \mathrm{~g}$ $\mathrm{kg}^{-1} \mathrm{TNT}$, while it was 0.013 for $10 \mathrm{~g} \mathrm{~kg}^{-1} \mathrm{TNT}$. Higher $\mathrm{C} / \mathrm{N}$ ratios led to higher $k^{\prime}$ regardless of TNT concentration when the system was aerated at $7 \mathrm{~L} \mathrm{~min}^{-1}$ (Table 2). On the other hand, $k^{\prime}$ did not significantly change using a lower aeration rate $\left(5 \mathrm{~L} \mathrm{~min}^{-1}\right)$ when different $\mathrm{C} / \mathrm{N}$ ratios were applied. TNT degradation rate was calculated as 0.024 for all tested TNT concentrations at $5 \mathrm{~L} \mathrm{~min}{ }^{-1}$ aeration rate. Exceptionally, $k^{\prime}$ was 0.022 when compost mixtures with $100 \mathrm{~g} \mathrm{~kg}^{-1}$ TNT was evaluated. This might be caused by lack of airflow or a local loss of microorganisms due to increase in temperature. Consistency in temperature profile and TNT degradation rate was achieved by combining $\mathrm{C} / \mathrm{N}=20$ with $5 \mathrm{~L} \min ^{-1}$ aeration rate, which were used in the remainder of TNT removal experiments in this report.
In Table 3, the results show the difference of the physical and microbiological parameters when isolated bacteria were not inoculated, inoculated with $0.1 \%$, and inoculated with $1 \%$ into in-vessel composting systems. Reduction in TNT concentration was shown to be $\sim 20 \%$ for non-inoculated mixtures, while it was almost $100 \%$ in inoculated compost mixtures operated at $\mathrm{C} / \mathrm{N}=20$ and $5 \mathrm{~L} \mathrm{~min}^{-1}$ aeration rate, implying that externallyintroduced TNT-degrading bacteria strains positively affected the TNT degradation process. In previous studies, the positive effect of externally-introduced bacteria on TNT removal was shown using composting systems. ${ }^{21,26,27}$

Evaluation of compost weight, $\mathbf{p H}$, and moisture. The changes in the organic matter affect carbon and nitrogen contents of the system which, in turn, influences $\mathrm{pH}$, temperature, and moisture of composting mixture as well as the compost weight. Biodegradation activity of the TNT-degrading bacteria leads to large weight losses of the composting mixtures. We, therefore, considered the weight loss as one of the main parameters to assess the microbial activity. In our system, combination of $\mathrm{C} / \mathrm{N}=20 / 1$ and $5 \mathrm{~L} \mathrm{~min}^{-1}$ aeration rate stimulated higher reduction in compost weight compared to other combinations (Table 3 ).

The reason for $\mathrm{pH}$ changes is the mineralization of the organic matter changes. As shown in Table 3 , initial $\mathrm{pH}$ values were in the range of 6.0-6.5, which increased to 7.0-7.3 at the end of the composting period. Typically, $\mathrm{pH}$ values gradually increased during experiments. This result is parallel to the observations in our previous work, in which TNT-degrading bacteria produced ammonia and nitrate during TNT degradation process. ${ }^{19}$ Accumulation of ammonia and nitrate eliminated organic content in the compost mixture under aerobic conditions. In this case, $\mathrm{pH}$ of the compost is expected to decrease rather than increase; however, $\mathrm{NH}_{4}-\mathrm{N}$ formation in compost could be the reason as it is favourable for microbial activity. ${ }^{28}$ The amount of $\mathrm{NH}_{4}-\mathrm{N}$ that was produced from degradation of $100 \mathrm{~g} \mathrm{~kg}^{-1}$ of TNT might affect the buffer system of composting. In the non-inoculated compost, where TNT degradation was quite low, $\mathrm{pH}$ also increased just as the inoculated composts, suggesting that $\mathrm{pH}$ increase might be triggered by the decomposition of the other compost amendments

Table 3 Physical and microbiological analysis at various conditions. Composting reactors were operated at $\mathrm{C} / \mathrm{N}=20 / 1$ and $5 \mathrm{~L}$ min ${ }^{-1}$ aeration rate. Results present the mean and standard deviation based on two experiments

\begin{tabular}{|c|c|c|c|c|c|c|}
\hline & \multicolumn{2}{|l|}{ No inoculation } & \multicolumn{2}{|c|}{$\begin{array}{l}\text { TNT-degrading bacteria } \\
\text { inoculation, } 0.1 \%(\mathrm{w} / \mathrm{w})\end{array}$} & \multicolumn{2}{|c|}{$\begin{array}{l}\text { TNT-degrading bacteria } \\
\text { inoculation, } 1 \%(\mathrm{w} / \mathrm{w})\end{array}$} \\
\hline & Initial & Final & Initial & Final & Initial & Final \\
\hline $\begin{array}{l}\text { TNT concentration } \\
\left(\mathrm{g} \mathrm{kg}^{-1}\right)\end{array}$ & $100.0000 \pm 2.9000$ & $80.0000 \pm 0.0010$ & $100.0000 \pm 2.9000$ & $0.0500 \pm 0.0020$ & $100.0000 \pm 3.1000$ & $0.0014 \pm 0.0003$ \\
\hline $\mathrm{C} / \mathrm{N}$ ratio & $19.9 \pm 1.1$ & $14.3 \pm 1.0$ & $19.9 \pm 0.2$ & $13.1 \pm 0.4$ & $19.9 \pm 0.7$ & $12.2 \pm 1.3$ \\
\hline $\begin{array}{l}\text { Bacteria cell numbers } \\
\text { (CFU per g) }\end{array}$ & $1.1 \times 10^{8}$ & $3.7 \times 10^{8}$ & $3.1 \times 10^{9}$ & $3.8 \times 10^{9}$ & $2.9 \times 10^{10}$ & $5.5 \times 10^{10}$ \\
\hline Moisture (\%) & $59.1 \pm 1.5$ & $57.5 \pm 1.1$ & $53.8 \pm 2.1$ & $50.1 \pm 3.4$ & $60.5 \pm 1.8$ & $57.6 \pm 2.5$ \\
\hline $\mathrm{pH}$ & $6.3 \pm 0.2$ & $7.1 \pm 0.1$ & $6.7 \pm 0.3$ & $7.3 \pm 0.1$ & $6.1 \pm 0.2$ & $7.1 \pm 0.2$ \\
\hline
\end{tabular}


such as food waste. Similar results were found by Unmar et al. ${ }^{29}$ reporting a gradual increase in $\mathrm{pH}$ because of the ammonia, nitrite and nitrate anion production in compost as a result of the microbial activity.

The changes of moisture content in different operational conditions are summarized in Table 3. Moisture content in all experiments was typically between $50-60 \%$, which provided suitable condition for microbial activity during composting treatment as previously stated by Spain et al. ${ }^{22}$ Although the conservation of moisture might depend on the water content of compost ingredients, a gradual decrease of moisture was observed during the composting process due to aeration and changes in temperature changes.

\section{Assessment of TNT degradation and effect of TNT-degrading bacteria strains}

This study showed that in-vessel composting system can effectively remediate TNT-amended soils by the help of externallyintroduced TNT-degrading bacteria. Laboratory-scale composting reactors were operated during 15 days, resulting in complete removal of TNT in aerobic conditions.

In our previous study, temperature and $\mathrm{pH}$ tolerances of the TNT-degrading bacteria strains were reported to be between 4-43 ${ }^{\circ} \mathrm{C}$ and 4.0-8.0, respectively. ${ }^{19}$ TNT-degrading bacteria strains in this study have maximum degradation activity at 20-43 ${ }^{\circ} \mathrm{C}$ and $\mathrm{pH}$ 6.0-7.0, which are in accordance with the previous reports. ${ }^{\mathbf{1 7 , 1 8 , 2 2 , 2 6}}$ Bacterial cell-number was counted several times over the course of the experiments from the soil samples that were collected from each reactor. The bacteria population density in the TNT-amended soil with $1 \%$ inocula was two orders of magnitude higher than that with no inoculation (Table 3). The bacterial counts of the non-inoculated composting mixtures were similar to typical values for biologically active soils. $^{26}$ These results also show that the noninoculated composting mixtures demonstrated negligible TNT removal, which might be mostly caused by activity of native microbes. In addition, in non-inoculated reactors containing $100 \mathrm{~g} \mathrm{~kg}^{-1}$ TNT, the ratio of initial and final bacteria cellnumbers was found to be lower than the inoculated ones. This might be a direct indication of successive survival of externally-introduced bacteria in TNT-amended environments. The results demonstrated in Table 3 are in agreement with previous studies, where bacteria cell numbers including Desulfovibrio sp. and Serratia plymuthica B7 strains were reported to degrade radiolabelled TNT. ${ }^{24,25}$ Similarly, the growth of Selenastrum capricornutum was reported in another study to be suppressed in the ongoing degradation process due to the presence of TNT. ${ }^{27}$

Temperature has been used to evaluate maturity of compost systems as suggested by Iglesias-Jimenez et al. ${ }^{30}$ Addition of $0.1 \%$ and $1 \%(\mathrm{w} / \mathrm{w})$ TNT-degrading bacteria consortiums triggered the temperature increase as seen in Fig. 3. Each in-vessel composting experiment contained consortiums with equal amounts of Citrobacter murliniae STE10, Achromobacter spanius STE11, Kluyvera cryocrescens STE12, and Enterobacter amnigenus STE13 bacteria strains in Fig. 3. Externally-introduced TNT-

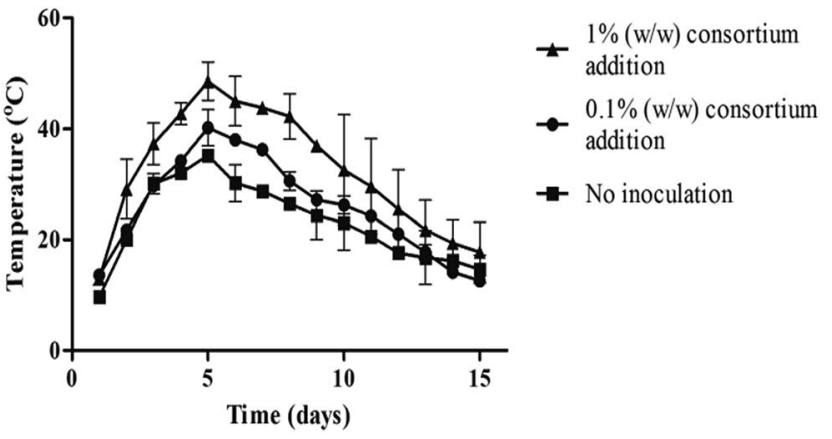

Fig. 3 Temperature change in in-vessel composting experiments for three different concentrations of TNT-degrading bacteria at $\mathrm{C} / \mathrm{N}=$ 20/1 and $5 \mathrm{~L} \mathrm{~min}^{-1}$ aeration rate. Error bars represent the standard deviation, $n=2$.

degrading bacteria actively involved in TNT degradation in the system because the temperature of inoculated compost mixtures was higher compared to non-inoculated ones.

Several transformation mechanisms by bacteria were previously demonstrated to be highly effective in biodegradation process such as transformation of TNT to 2,4,6-triaminotoluene, diaminonitrotoluene, aminodinitrotoluenes, and 4-amino-2,6dinitrotoluenes by co-metabolic reduction of nitro groups. ${ }^{22,27}$ In this study, hydrophilic interactions or formation of coplanar electron-acceptor complexes may play a role in association of TNT metabolites to the organic mixture. Despite ADNTs are initial TNT transformation products with an aromatic ring staying intact, minute amounts of ADNTs were observed between days 5-10 (Fig. 4), indicating that TNT might have been aerobically converted to more biodegradable forms and further degradation products bound to the soil irreversibly. ${ }^{22,32}$ Nucleophilic addition of the amino groups to carbonyl groups or aromatic carbons may result in adherence to humic substances. ${ }^{31}$ Complete removal of extreme TNT concentrations $\left(100 \mathrm{~g} \mathrm{~kg}^{-1}\right)$ was achieved within 15 days under aerobic conditions by our in-vessel composting method with the addition of

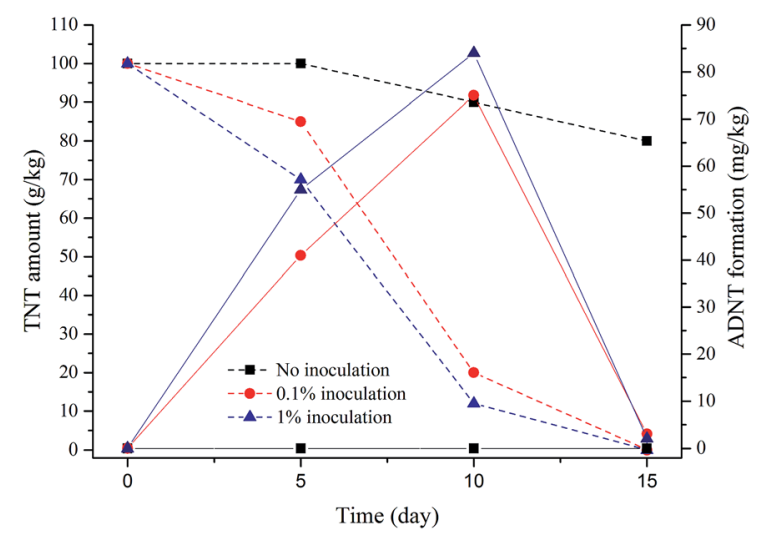

Fig. 4 Changes in TNT and ADNT amounts in composts with different concentrations of TNT-degrading bacteria (at $\mathrm{C} / \mathrm{N}=20 / 1$ and $5 \mathrm{~L} \mathrm{~min}^{-1}$ aeration rate). TNT and ADNT amounts are presented in dashed and continuous lines, respectively. Error bars present the standard deviation, $n \geq 3$. 
Table 4 Shoot growth of plant species that were cultivated in greenhouse soil amended with $100 \mathrm{~g} \mathrm{~kg}^{-1}$ of TNT, final compost mixture, and nonamended greenhouse soil. Error bars present the standard deviation, $n \geq 3$

\begin{tabular}{|c|c|c|c|c|c|c|}
\hline \multirow[b]{2}{*}{ Plant species } & \multicolumn{2}{|c|}{$100 \mathrm{~g} \mathrm{~kg}^{-1}$ TNT amended soil } & \multicolumn{2}{|c|}{ Final compost mixture } & \multicolumn{2}{|c|}{ Non-amended soil } \\
\hline & $\begin{array}{l}\text { Shoot length } \\
\text { in week } 1(\mathrm{~cm})\end{array}$ & $\begin{array}{l}\text { Shoot length in } \\
\text { week } 10(\mathrm{~cm})\end{array}$ & $\begin{array}{l}\text { Shoot length in } \\
\text { week } 1(\mathrm{~cm})\end{array}$ & $\begin{array}{l}\text { Shoot length in } \\
\text { week } 10(\mathrm{~cm})\end{array}$ & $\begin{array}{l}\text { Shoot length in } \\
\text { week } 1(\mathrm{~cm})\end{array}$ & $\begin{array}{l}\text { Shoot length in } \\
\text { week } 10(\mathrm{~cm})\end{array}$ \\
\hline Pelargonium & $2.1 \pm 0.1$ & $3.6 \pm 0.1^{a}$ & $2.3 \pm 0.2$ & $20.0 \pm 1.0$ & $1.9 \pm 0.3$ & $21.5 \pm 0.5$ \\
\hline Tomato & $2.8 \pm 0.1$ & $3.5 \pm 0.2$ & $2.5 \pm 0.3$ & $13.4 \pm 0.2$ & $2.7 \pm 0.0$ & $13.0 \pm 0.2$ \\
\hline Wheat & $4.3 \pm 0.4$ & $5.0 \pm 0.1^{a}$ & $3.9 \pm 0.4$ & $26.2 \pm 1.5$ & $4.3 \pm 0.1$ & $26.4 \pm 1.5$ \\
\hline
\end{tabular}

${ }^{a}$ The colour of the plant turned into yellow.

TNT-degrading strains of bacteria; Citrobacter murliniae STE10, Achromobacter spanius STE11, Kluyvera cryocrescens STE12, and Enterobacter amnigenus STE13. These results are similar to the study suggesting TNT biotransformation activity by Salmonella typhimurium, Desulfovibrio sp. and Clostridium fermetans isolates in soil. ${ }^{27}$

\section{Toxicity test}

The growth observations suggested that the negative effect of TNT varied between seedlings. ${ }^{10,22}$ Shoot length decreased significantly with extreme TNT contamination. ${ }^{31,33}$ While the shoot length was in the range of 1.9-4.6 cm for all seedlings in the $1^{\text {st }}$ week, the growth was significantly inhibited in $100 \mathrm{~g} \mathrm{~kg}^{-1}$ TNT-amended greenhouse soil. After 10 weeks of growth, pelargonium and wheat were observed to be faint. When compared to TNT-amended soil, shoot length average was 16.4, $10,21.2,26 \mathrm{~cm}$ longer in remediated compost for pelargonium, tomato, wheat, corn, respectively (Table 4). Corn and geranium were more TNT sensitive compared to wheat and tomato since the growth of each species was slow in TNT-amended greenhouse soil compared to the same plants in non-amended greenhouse soil. ${ }^{10}$ ESI, S1† shows the growth of seedlings in final compost in their growth in $1^{\text {st }}$ (ESI, S1a $\dagger$ ) and in $10^{\text {th }}$ weeks (ESI, S1b-e $\dagger$ ). These results indicate that seedlings in final compost mixtures grew as fast as the ones in non-amended greenhouse soil. These results are similar to the growth of two dicotyledons and two monocotyledons in TNT-contaminated soils reported by Gong et al. ${ }^{34}$

\section{Conclusions}

This study describes complete removal of high TNT concentrations in 15 days using an in-vessel composting system enabled by the addition of Citrobacter murliniae STE10, Achromobacter spanius STE11, Kluyvera cryocrescens STE12, and Enterobacter amnigenus STE13 strains. Our findings indicate that TNT removal rate is affected by $\mathrm{C} / \mathrm{N}$ ratio, aeration rate and the concentration of externally-introduced TNT-degrading bacteria consortium. Highest removal occurred at the combination of $\mathrm{C} / \mathrm{N}=20 / 1$ and $5 \mathrm{~L} \mathrm{~min}^{-1}$ aeration rate, where $49.1^{\circ} \mathrm{C}$ was observed as the highest temperature. TNT degradation rate remained unvaried $\left(k^{\prime}=0.024\right)$ for all combinations of tested parameters when $5 \mathrm{~L} \min ^{-1}$ aeration was kept constant.
Initial TNT concentration did not have impact on TNT removal rate and compost maturation. Addition of TNTdegrading bacteria consortium stimulated TNT removal and ADNT formation, which was not observed in non-inoculated composting reactors. ${ }^{32,35}$ Duration of the composting process, however, was not significantly influenced by TNT-degrading bacteria addition. Toxicity test indicated that the growth of seedlings in final composts was similar to the growth in nonamended greenhouse soils, and showed no toxic effect. This work reports the highest TNT degradation rate that was observed in the shortest period by the use of in-vessel composting process, thus it can potentially be applied in TNTcontaminated areas as an efficient bioremediation strategy.

\section{Acknowledgements}

Financial support was provided by the Republic of Turkey, Ministry of Science Industry and Technology under the Project no. STZ-00480-2009-2. The authors would like to thank Zafer Pesen from the Mechanical and Chemical Industry Corporation and Halil Karatas from the Brass Factory for their collaboration. Additionally, the authors thank Fuat Gökbel, Füsun Tamer, Burhan Aydoğdu, and Bülent Şahiner for their help in composting and greenhouse studies.

\section{Notes and references}

1 S. Letzel, T. Göen, M. Bader, J. Angerer and T. Kraus, Occup. Environ. Med., 2003, 60, 483.

2 Environmental Protection Agency, Health Advisory for TNT, Criteria and Standard Division, Office of Drinking Water, Washington, 1989.

3 P. G. Rieger and H. J. Knackmuss, Basic knowledge and perspectives on biodegradation of 2,4,6-trinitrotoluene and related nitroaromatic compounds in contaminated soil, in Biodegradation of nitroaromatic compounds, ed. J. C. Spain, New York, 1995.

4 H. Black, Environ. Health Perspect., 1995, 103, 1106.

5 K. Brennan, Personal Communication, The Food Project, 2002.

6 B. D. Ensley and I. Raskin, Phytoremediation of Toxic Metals, New York, 2000.

7 R. Malot, Personal communication: Terravac, 2002. 
8 J. Murland, Personal Communication, President, EnviroLogic Inc./Spillaway, 2002.

9 M. A. Major, W. H. Griest, J. C. Amos and W. G. Palmer, "Study Number 87-3012-95: Evidence for the Chemical Reduction and Binding of TNT During the Composting of Contaminated Soils March 1995-January 1996 (no. USACHPPM-87-3012-95:)", Army center for health promotion and preventive medicine (provisional), Aberden proving ground md, 1997.

10 M. R. Rezaei, M. A. Abdoli, A. Karbassi, A. Baghvand and R. Khalilzadeh, Soil Sediment Contam., 2010, 19, 504.

11 N. Fahrenfeld, J. Zoeckler, M. A. Widdowson and A. Pruden, Biodegradation, 2013, 24, 179.

12 J. L. Osmon and C. C. Andrews, The biodegradation of TNT in enhanced soil and composting systems, U.S.Army Armament Research and Development Command, ARLCD-TR77032, National Technical Information Service publication no. ADE400073, Nationalechnical Information Service, Springfield, Dover, N.J, 1978.

13 J. Breitung, D. Bruns-Nagel, K. Steinbach, L. Kaminski, R. Haas, D. Gemsa and E. Von Löw, Appl. Microbiol. Biotechnol., 1996, 44, 795.

14 D. Bruns-Nagel, O. Drzyzga, K. Steinbach, T. C. Schmidt, E. Von Löw, T. Gorontzy, K. H. Blotevogel and D. Gemsa, Environ. Sci. Technol., 1998, 32, 1676.

15 D. Cekmecelioglu, A. Demirci, R. E. Graves and N. H. Davitt, Biosystems. Eng., 2005, 91, 479.

16 B. Antizar-Ladislao, K. Spanova, A. J. Beck and N. J. Russell, Int. Biodeterior. Biodegrad., 2008, 61, 357-364.

17 R. Canet, J. G. Birnstingl, D. G. Malcolm, J. M. Lopez-Real and A. J. Beck, Bioresour. Technol., 2001, 76, 113.

$18 \mathrm{~J}$. Sambrook and D. W. Russell, Molecular cloning: A laboratory manual, New York, 2001.
19 B. Gumuscu and T. Tekinay, Int. Biodeterior. Biodegrad., 2013, 85, 35.

20 N. Rijpens, G. Vlaemynck, R. Rossau, L. Herman and G. Jannes, Lett. Appl. Microbiol., 1998, 27, 198.

21 M. D. de Bertoldi, G. E. Vallini and A. Pera, Waste Manage. Res., 1983, 1, 157.

22 J. C. Spain, J. B. Hughes and H. J. Knackmuss, Biodegradation of nitroaromatic compounds and explosives, Florida, 2000.

23 S. Gakvagno, F. Fortuna, G. Cornacchia, S. Casu, T. Coppola and V. K. Sharma, Energy Convers. Manage., 2000, 42, 573.

24 B. Gumuscu, Z. Erdogan, M. O. Guler and T. Tekinay, PLoS One, 2014, 9, e99230.

25 A. D. Neklyudov, G. N. Fedotov and A. N. Ivankin, Appl. Biochem. Microbiol., 2008, 44, 6.

26 O. Drzyzga, D. Bruns-Nagel, T. Gorontzy, K. H. Blotevogel, D. Gemsa and E. Von Löw, Curr. Microbiol., 1998, 37, 380.

27 W. D. Won, L. H. DiSalvo and J. Ng, Appl. Environ. Microbiol., 1976, 31, 576.

28 E. P. Best, S. L. Sprecher, H. L. Fredrickson, M. E. Zappi and S. L. Larson, Army engineer waterways experiment station, ms environmental lab, Vicksburg, 1997, No. WES-TR-EL-97-24.

29 G. Unmar and R. Mohee, Bioresour. Technol., 2008, 99, 6738.

30 E. Iglesias-Jimenez and V. Perez-Garcia, Agric., Ecosyst. Environ., 1992, 38, 331.

31 R. Liu, T. Zhang, Z. Zhou and L. Yang, RSC Adv., 2014, 19, 9810-9818.

32 T. Tekinay and B. Gumuscu, Curr. Opin. Biotechnol., 2011, 22, S66.

33 M. J. Strynara, J. Deca and J. M. Bollaga, Biorem. J., 2002, 6, 177.

34 P. Gong, B. M. Wilke and S. Fleischmann, Arch. Environ. Contam. Toxicol., 1999, 36, 152.

35 J. Hawari, S. Beaudet, A. Halasz, S. Thiboutot and G. Ampleman, Appl. Microbiol. Biotechnol., 2000, 54, 605. 